\title{
Reviews on common objectives and evaluation indicators for risk communication activities from 2011 to 2017
}

\author{
Akiko Sato ${ }^{1}$, Kaori Honda ${ }^{1}$, Kyoko Ono ${ }^{2}$, Reiko Kanda ${ }^{3}$, Takehiko I Hayashi ${ }^{4}$, Yoshihito Takeda ${ }^{5}$, Yoshitake \\ Takebayashi $^{1}$, Tomoyuki Kobayashi ${ }^{1,6}$, Michio Murakami $^{\text {Corresp. } 1}$ \\ 1 Department of Health Risk Communication, Fukushima Medical University School of Medicine, Fukushima, Japan \\ 2 Research Institute of Science for Safety and Sustainability, National Institute of Advanced Industrial Science and Technology, Ibaraki, Japan \\ 3 Quantum Medical Science Directorate, National Institute for Quantum and Radiological Science and Technology, Chiba, Japan \\ ${ }^{4}$ Center for Health and Environmental Risk Research, National Institute for Environmental Studies, Ibaraki, Japan \\ 5 Department of Risk Management and Environmental Sciences, Graduate School of Environment and Information Sciences, Yokohama National \\ University, Kanagawa, Japan \\ 6 Research Fellow of Japan Society for the Promotion of Science, Fukushima, Japan \\ Corresponding Author: Michio Murakami \\ Email address: michio@fmu.ac.jp
}

Background. Risk communication is widely accepted as a significant factor for policy makers, academic researchers, and practitioners in diverse fields. However, there remains a lack of comprehensive knowledge about how risk communication is currently conducted across fields and about the way risk communication is evaluated. Methodology. This study systematically searched for materials from three scholarly search engines and one journal with a single search term of "risk communication." The eligibility assessment selected peer-reviewed articles published in English that evaluated risk communication activities. Emphasis was placed on articles published in recent years accounting for about half of the pre-selected ones. Data on field of study, intervention timing, target audience, communication type, and objectives/evaluation indicators was extracted from the articles. Patterns of objectives/evaluation indicators used in risk communication activities were compared with those of the definitions and purposes of risk communication stated by relevant organizations. Association analysis was conducted based on study fields and objectives/evaluation indicators. Results. The screening process yielded 292 articles that were published between 2011 and 2017 in various fields, such as medicine, food safety, chemical substances, and disasters/emergencies. The review process showed that many activities were performed in the medical field, during non-/pre-crisis periods. Recent activities primarily targeted citizens/Non-Profit Organizations (NPOs), and was disseminated in the form of large group or mass communication. While "knowledge increase," "change in risk perception and concern alleviation," and "decision making and behavior change" were commonly addressed in practice, "trust-building" and "reduction in 
psychological distress" were rarely focused. The analysis also indicated that the medical field tends to perform risk communication at the individual or small group level, in contrast to the food safety field. Further, risk communications in the non-/pre-crisis period are more likely to aim at "changes in risk perception and concern alleviation" than those in the crisis period. Risk communications that aim at "changes in risk perception and concern alleviation" are likely to be presented in a large group or mass communication, whereas those that aim at "decision making and behavior change" are likely to be conducted at the individual or small group level. Conclusion. An overview of recent activities may provide those who engage in risk communication with an opportunity to learn from practices in different fields or those conducted in different intervention timings. Devoting greater attention to trust building and reduction in psychological distress and exploring noncitizen/NPO stakeholders' needs would be beneficial across academic and professional disciplines. 
1 Reviews on Common Objectives and Evaluation Indicators for Risk 2 Communication Activities from 2011 to 2017

3

4 5 6

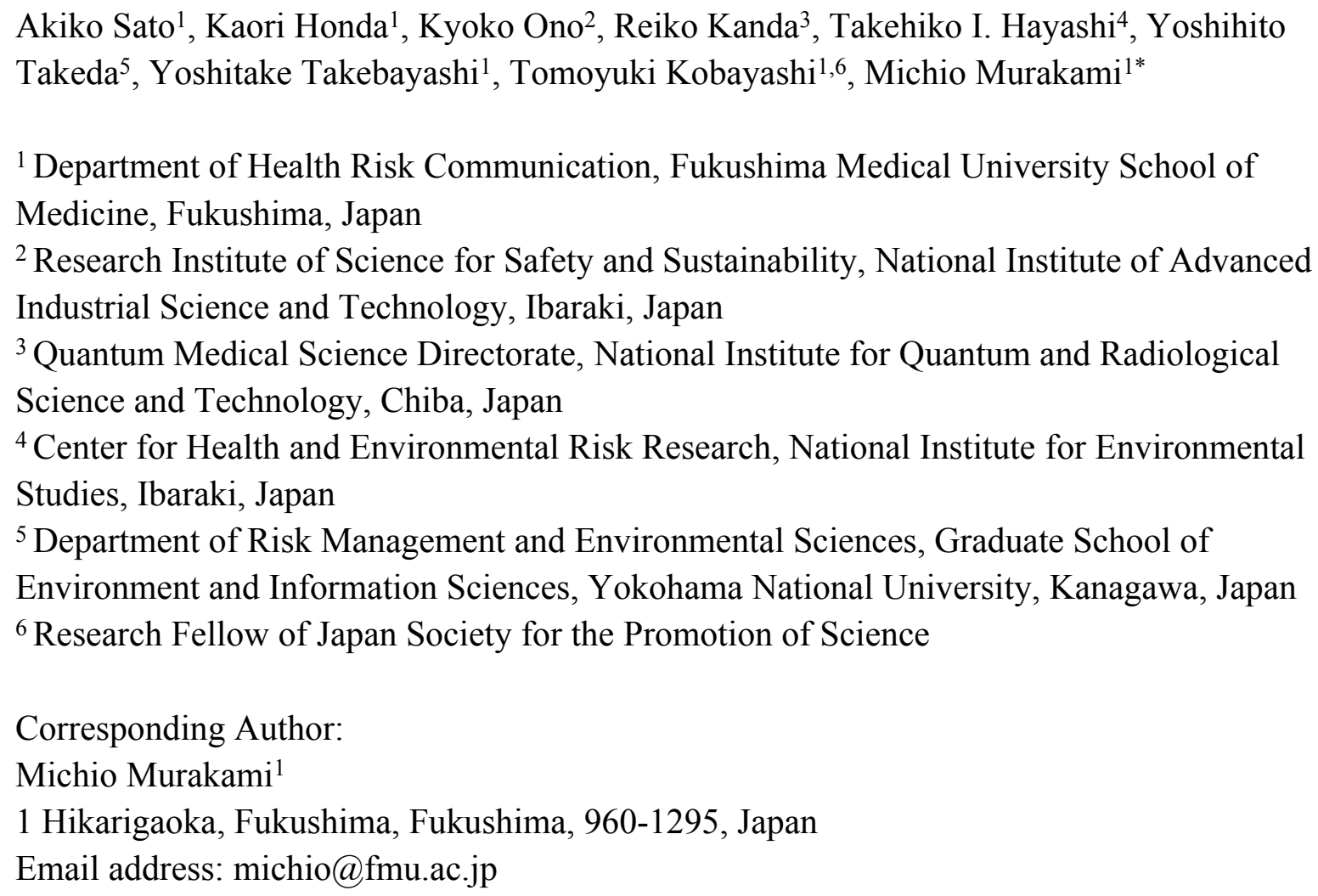

\section{Abstract}

Background. Risk communication is widely accepted as a significant factor for policy makers, academic researchers, and practitioners in diverse fields. However, there remains a lack of comprehensive knowledge about how risk communication is currently conducted across fields and about the way risk communication is evaluated.

Methodology. This study systematically searched for materials from three scholarly search engines and one journal with a single search term of "risk communication." The eligibility assessment selected peer-reviewed articles published in English that evaluated risk communication activities. Emphasis was placed on articles published in recent years accounting for about half of the pre-selected ones. Data on field of study, intervention timing, target audience, communication type, and objectives/evaluation indicators was extracted from the articles. Patterns of objectives/evaluation indicators used in risk communication activities were compared with those of the definitions and purposes of risk communication stated by relevant 
36

37

38

39

40

41

42

43

44

45

46

47

48

49

50

51

52

53

54

55

56

57

58

59

60

61

62

63

64

65

66

67

68

69

70

71

72

73

74

organizations. Association analysis was conducted based on study fields and objectives/evaluation indicators.

Results. The screening process yielded 292 articles that were published between 2011 and 2017 in various fields, such as medicine, food safety, chemical substances, and disasters/emergencies. The review process showed that many activities were performed in the medical field, during non/pre-crisis periods. Recent activities primarily targeted citizens/Non-Profit Organizations (NPOs), and was disseminated in the form of large group or mass communication. While "knowledge increase," "change in risk perception and concern alleviation," and "decision making and behavior change" were commonly addressed in practice, "trust-building" and "reduction in psychological distress" were rarely focused. The analysis also indicated that the medical field tends to perform risk communication at the individual or small group level, in contrast to the food safety field. Further, risk communications in the non-/pre-crisis period are more likely to aim at "changes in risk perception and concern alleviation" than those in the crisis period. Risk communications that aim at "changes in risk perception and concern alleviation" are likely to be presented in a large group or mass communication, whereas those that aim at "decision making and behavior change" are likely to be conducted at the individual or small group level.

Conclusion. An overview of recent activities may provide those who engage in risk communication with an opportunity to learn from practices in different fields or those conducted in different intervention timings. Devoting greater attention to trust building and reduction in psychological distress and exploring non-citizen/NPO stakeholders' needs would be beneficial across academic and professional disciplines.

\section{Introduction}

The COVID-19 pandemic made the world-from politicians, scholars and practitioners to individual citizens - desperate for accurate, timely information. As of June 2020, there is no single day during which one does not hear updates or stories related to COVID-19. Not only reliable information, but myths and false messages have also spread rapidly, causing great confusion. Such incorrect information sometimes results in unnecessary fear or unrealistic hope among people [1,2]. In response to the upsurge in demand from affected nations, the International Federation of Red Cross and Red Crescent Societies (IFRC), the United Nations Children's Fund (UNICEF), and the World Health Organization (WHO) jointly issued the COVID-19 Global Response: Risk Communication and Community Engagement (RCCE) Strategy [3]. The world is now keen on effective risk communication.

Although risk communication is now gaining tremendous attention, it is not new. In 1989, the United States National Research Council published Improving Risk Communication [4] and introduced an influential concept of risk communication by calling it:

An interactive process of exchange of information and opinion among individuals, groups, and institutions. It involves multiple messages about the nature of risk and other 
75

76

77

78

79

80

81

82

83

84

85

86

87

88

89

90

91

92

93

94

95

96

97

98

99

100

101

102

103

104

105

106

107

108

109

110

111

112

113

messages, not strictly about risk, that express concerns, opinions, or reactions to risk messages or to legal and institutional arrangements for risk management. [4]

The concept has been ardently applied to avert the occurrence of different risks in life and reduce their impacts on human health, property and the environment [5-7]. Apart from public health emergencies such as COVID-19, risk communication can take place in other areas, involving health care, food safety, and chemical substances [8-11]. Risk communication is embedded in many aspects of everyday life.

In response to a growing awareness of the importance of risk communication, numerous organizations which are responsible for communicating about risk management strategies have presented their views on risk communication to facilitate its application. Table 1 summarizes examples of the definitions and purposes of risk communication stated by some leading organizations in their respective areas, involving United Nations organizations, the European Union, and other intergovernmental organizations, as well as national government departments and agencies. The table illustrates that organizations consider risk communication to be the transfer and exchange of risk-related information and opinions. Common purposes of risk communication across the organizations are (1) knowledge increase, (2) communication satisfaction, (3) change in risk perception and concern alleviation, (4) reduction in psychological distress, (5) trust building, (6) decision making and behavior change, and (7) self-efficacy improvement. Some organizations also include "facilitation of mutual understanding" and "citizen participation in policy making" as a part of the purpose of risk communication.

\section{Table 1. Definitions and purposes of risk communication as stated by select international and national organizations.}

\section{(Table 1 around here)}

The dynamic nature of risk communication, with these diverse purposes, makes it complex to transfer concepts into practice. As Lundgren and McMakin describe in Risk Communication: A Handbook for Communicating Environmental, Safety, and Health Risks [28], risk communication may require different communication methods (e.g., oral, visual, other, or combined approaches; face-to-face and mass communication) and different concerned parties depending on risk characteristics, the surrounding circumstances, audience, and communication purposes. It is not necessarily straightforward to comprehend the purpose and method of risk communication or how its effects are measured in a given field. Further, it is even more cumbersome to grasp overall trends in risk communication practices and evaluation methods across different fields.

Peer] reviewing PDF | (2020:03:46457:1:0:NEW 26 Jun 2020) 
114 There are studies that have reviewed risk communication activities and their evaluation methods

115 within a specific field [29,30]. However, the authors find that there is still a lack of synergetic

116 research that provides a comprehensive overview. For that reason, this study attempted to

117 identify and summarize the main objectives, approaches, and evaluation indicators applied for

118 risk communication activities across fields. Furthermore, this study sought to investigate whether

119 any discrepancies existed between prominent organizations' perspectives and expectations on

120 risk communication and their respective practices.

\section{Methodology}

\section{Inclusion and Exclusion Criteria}

123 The inclusion criteria used to select empirical studies were (1) that the study evaluates risk

124 communication activities in any field, and (2) that the study is written in English. This study also

125 included previous research that did not directly evaluate risk communication but did ask

126 implementers, such as medical professionals, about the objectives and effects of their activities

127 relevant to risk communication. These studies were included because they provided insight into

128 the objectives/evaluation of risk communication that is expected. Review studies, commentaries,

129 conference proceedings, and books were excluded. Since abstracts were reviewed during the first

130 round of eligibility assessment, materials that did not provide an abstract were excluded. Articles

131 that discuss the procedures of future risk communication activities - meaning that the activities

132 had not been implemented at the time of publication — were also excluded.

\section{Search Strategy}

134 Potential materials for this study were identified on April 18, 2018, through relevant search 135 engines, namely, PubMed, ScienceDirect, and PsycINFO. These sources are accepted as the 136 world's leading scholarly search engines since they provide access to peer-reviewed literature in 137 a wide range of academic disciplines. The only search term used was "risk communication." The 138 Journal of Risk Research was also included as a source for the material collection because this 139 journal contains many study articles on the topic of risk communication that are not covered by 140 these search engines. Initially, the material search was not limited by the year of publication to 141 learn how the number of publications related to risk communication activities has shifted over 142 time. After eliminating duplicates and articles that did not provide an abstract, and obtaining a 143 solid idea about the number of possibly eligible studies, the authors used this information to 144 determine the span of publication years from which studies would be included. This time span 145 includes approximately half of the relevant materials published in recent years.

\section{Eligibility Assessment}

147 This study conducted two rounds of eligibility assessment. As it is briefly stated above, the first 148 round was a review of only titles and abstracts of articles that were identified through the search 
149

150

151

152

153

154

155

156

157

158

159

160

161

162

163

164

165

166

167

168

169

170

171

172

173

174

175

176

177

178

179

180

181

182

183

184

185

186

engines and the Journal of Risk Research. This initial assessment was to pre-select materials from which to derive the eligibility criteria for this study and to obtain a broad picture of recent risk communication activities in order to finalize a plan for subsequent analysis. The second round involved a review of full texts of pre-selected articles to confirm their eligibility.

For the first round of eligibility assessment, the team established groups consisting of two researchers. Each researcher independently assessed assigned articles and determined whether the study (1) evaluated risk communication activities quantitatively, (2) assessed the objectives and/or effects of risk communication activities qualitatively, and (3) discussed the objectives and/or effects of risk communication activities based on prior experiences and/or existing scientific knowledge. For the second round, researchers were re-grouped, and a pair of researchers independently read assigned articles that they had not checked during the first round to confirm the eligibility of the articles and finalize the material selection.

The principal investigator of the research project (MM) coordinated this evaluation and selection process. MM checked all articles and developed a basic protocol for the eligibility assessment. In general, if both reviewers who checked a particular article agreed in their evaluation of its eligibility, the decision was accepted. When there was a disagreement, MM facilitated discussions between the researchers to achieve consensus. When necessary, MM reflected the points of agreement in the protocols to ensure consistency in evaluation.

\section{Coding Process}

After completion of the first round of eligibility assessment, the research team discussed what data should be extracted and how the information should be labeled and coded. The team made decisions based on characteristics of risk communication activities learned from the first round of eligibility assessment, the international and national organizations' statements on risk communication (Table 1) and other relevant literature, as well as individual researchers' experience and expertise.

Researchers remained in the same group formed for the second round of eligibility assessment, and separately extracted data from each assigned article and coded it as follows:

- Evaluation approach: (1) quantitative, (2) qualitative, and (3) based on prior experience and/or existing scientific knowledge (see the criteria in "Eligibility Assessment").

- Study field: (1) medicine, such as health and pharmaceutical realms, (2) food safety, (3) chemical substances (other than food safety matters), (4) nuclear and radiological disasters/emergencies, (5) other disasters/emergencies, (6) climate change, and (7) other.

- Timing when a risk communication intervention was implemented in line with the phases in the disaster management cycle: (1) non-crisis or pre-crisis, including non-specified, (2) crisis, and (3) post-crisis, including recovery phase. 
187

188

189

190

191

192

193

194

195

196

197

198

199

200

201

202

203

204

205

206

207

208

209

210

211

212

213

214

215

216

217

218

219

220

221

222

223

- Target audience: (1) citizens (e.g., individual citizens, residents, unspecified persons, and citizen groups) or Non-Profit Organizations (NPOs), and (2) other (e.g., government, professionals, and companies).

- Communication type: (1) individual/small group communication (e.g., doctor-patient-family communication and family communication), and (2) large-group/mass communication.

- Objective/indicator: (1) knowledge increase, (2) communication satisfaction, (3) change in risk perception and concern alleviation, (4) reduction in psychological distress, (5) trust building, (6) decision making and behavior change (e.g., risk acceptance, risk avoidance, and risk management, such as avoidance of unhealthy foods, seeking healthcare, disaster mitigation and preparedness, and community partnerships; attitude toward behavior and behavioral intention were also included in this category), (7) self-efficacy improvement, and (8) other.

With regard to "intervention timing", this study employed the three-stage approach proposed by Coombs [31]. The term "crisis" in this study refers to the definition proposed by the same scholar [32] as, "a significant threat to operations that can have negative consequences if not handled properly." The pre-crisis period involves the detection of warning signs relating to such crisis and prevention and/or preparedness. The crisis period concentrates on identifying the onset of a crisis, controlling the situation, and minimizing negative impacts. The post-crisis period concerns rehabilitation and full recovery from the crisis, evaluation of crisis management, and better preparation for future crisis [31]. With regard to "objective/evaluation indicator", the researchers jointly determined how indicators should be classified by referring to the definitions and purposes of risk communication stated by the selected international and national organizations (Table 1).

Where applicable, multiple response categories were selected. If both reviewers who checked a particular article classified it the same way, the decision was accepted. When the two researchers differed, discrepancies were evaluated by a third researcher. When needed, the issues were discussed with MM until all concerned researchers reached an agreement on the article's classification.

Examples of evaluation indicators were drawn for this paper. Specifically, one example for each indicator was taken from the field of medicine, and another was from other fields due to the generally large number of relevant medicine-related articles. Examples were chosen based on the frequency of citation assessed on May 10, 2019 through Google Scholar and the clarity of applied methods. Even if some frequently cited studies targeted multiple indicators, they were referred to for only one indicator among all the applicable indicators. 


\section{Statistical Analysis}

225 Data was entered into a Microsoft Office Excel spreadsheet. Excel was used to compute 226 descriptive information on the collected data. Additionally, sets of Pearson's chi-squared test 227 with Yates's continuity correction and Fisher's exact test were conducted to examine the 228 associations by study field and by objective/evaluation indicator. The statistical analyses were 229 performed with studies that belonged to a single category of all the variables except for the 230 variable of "objective/evaluation indicator". "Nuclear and radiological disasters/emergencies," 231 "climate change," and "other" from the study field variable were excluded because of their small 232 size. For the same reason, the "crisis" group and "post-crisis" group were combined in the 233 analysis on the associations by study field, and the "crisis" group was excluded in the analysis on 234 the associations by objectives/evaluation indicators. For analyses involving study field, post hoc 235 test [33] was conducted to determine where differences occurred if an initial analysis identified a 236 significant difference between study field and other variables. R [34] was used for the statistical 237 analyses. Test results were considered significant at $P<0.05$. $P$-value adjustment by Holm's 238 method was applied for multiple comparisons.

\section{Results}

240

241

242

243

244

245

246

247

248

249

250

251

252

253

254

255

256

257

258

\section{Search Results}

Figure 1 summarizes the flow of the material search and selection for this study. The database search found 3,710 articles, mostly from PubMed (57\%). Of those, 1,433 articles went through the first round, and 412 moved on to the second round of eligibility assessment. In the end, 292 articles published between 2011 and 2017 remained for review.

(Figure 1 around here)

Figure 1. Flow diagram of material selection. JRR = Journal of Risk Research

\section{Characteristics of Risk Communication Studies}

The data generated for this study is provided in Table S1. The table contains basic information from all 292 articles. Figure 2 shows a descriptive summary of the data.

(Figure 2 around here)

Figure 2. Descriptive statistics of the study variables $(N=292)$. 
259

260

261

262

263

264

265

266

267

268

269

270

271

272

273

274

275

276

277

278

279

280

281

282

283

284

285

286

287

288

289

290

291

292

293

294

295

More than $80 \%$ of the studies quantitatively evaluated own risk communication practices. Over $60 \%$ were related to medicine. Studies classified as "other" included those addressing humanwildlife conflicts [35] and traffic safety [36,37], as well as studies that used a risk scenario or involved multiple risk domains to investigate effective means or to assess intrapersonal and other factors of risk communication [38,39]. Five studies (2\%) fell in multiple study fields. The vast majority of activities were implemented during a non-/pre-crisis phase (93\%), and one study involved multiple phases. Over $90 \%$ of the studies targeted citizens/NPOs. Of those, 15 studies or 5\% also approached other target groups, such as medical professionals and farmers. As for communication type, more than $60 \%$ were communications to a large group audience or the public. Of those, seven studies or $2 \%$ were also conducted in the form of individual/small group communication. Frequently-used objectives/evaluation indicators were "decision making and behavior change," "change in risk perception and concern alleviation," and "knowledge increase" (61\%, 44\%, and 39\%, respectively). Examples of objectives/evaluation indicators are shown in Table 2.

Table 2. Evaluation examples from risk communication studies.

(Table 2 around here)

\section{Comparison between Risk Communication Definitions and Purposes and Main Objectives/Evaluation Indicators}

The authors of this study identified "knowledge increase," "change in risk perception and concern alleviation," and "decision making and behavior change" as areas of focus in all fields; these objectives are also discussed in the definitions and purposes of most organizations and agencies (Figure 2, Table 1). Here, "knowledge" is about the risks of concern and related risk management policies and actions. "Change in risk perception" primarily focused on guiding individuals' subjective judgment of risk to align with available scientific evidence. Table 1 also illustrates that "reduction in psychological distress" does not generally appear in the selected organizations' definitions and purposes of risk communication, which is consistent with this study; this topic was rarely addressed in the studies reviewed in this research (2\%).

In contrast, "trust building" is frequently included among the proposed purposes of risk communication, whereas it was rarely addressed in the studies assessed in this research (8\%).

Further, while the organizations extended the target of risk communication in their statements to non-citizen parties, such as industries and media, those groups were rarely targeted in risk communication activities in the studies assessed in this research. Consequently, relevant indicators were not discussed in the study articles. 
296

297

298

299

300

301

302

303

304

305

306

307

308

309

310

311

312

313

314

315

316

317

318

319

320

321

322

323

324

325

326

327

328

329

330

331

332

333

\section{Differences by Study Field}

Table 3 shows the frequency data, which is cross-tabulated with study field and other variables. In most fields of study, risk communication activities were conducted in a non-/pre-crisis phase, whereas nearly half of the risk communications in the field of nuclear and radiological disasters/emergencies were conducted in a non-/pre-crisis phase, and the remaining were in a post-crisis phase. The table shows that the majority of risk communication targets citizens/NPOs. At the same time, $29 \%$ in the field of chemical substances targeted other groups. In the medical field, half of the risk communications were conducted at an individual level or in a small group, whereas risk communication in other fields was conducted mainly in a larger group or to an entire population of interest.

\section{Table 3. Intervention timing, target audience, and communication type by study field} $(N=292)$.

\section{(Table 3 around here)}

Table S2 shows the results of the analyses between study field and other variables. The series of analyses found significant associations between study field and communication type $(P<0.01)$. Multiple comparisons suggested a significant difference pertaining to communication type between risk communications in the field of medicine from those in food safety $(P<0.05)$.

\section{Differences by Objective/Evaluation Indicator}

Table 4 highlights the diversity in objectives and indicators of risk communication activities. For instance, the fields of food safety and other (i.e., non-nuclear/radiological) disasters and emergencies had a higher percentage in terms of risk communications aiming or addressing "trust building" ( $22 \%$ and $19 \%$, respectively) than other fields, especially compared to the field of medicine (5\%). The chemical substance field had a higher percentage $(76 \%)$, and the field of nuclear and radiological disasters/emergencies had a lower percentage (33\%) compared with other fields with regard to risk communications focusing on "decision making and behavior change."

\section{Table 4. Study field, intervention timing, target audience, and communication type by objective/evaluation indicator $(N=292)$.}

\section{(Table 4 around here)}

Table 4 also suggests some percentage differences in intervention timing, target audience, and communication type by objective/evaluation indicator. The main objectives and indicators of risk communications conducted in a non-/pre-crisis period were "knowledge increase," "change in 
334 risk perception and concern alleviation," and "decision making and behavior change" (39\%, $33545 \%$, and $62 \%$, respectively). "Decision making and behavior change" was a main indicator for 336 risk communications conducted in a crisis period (57\%). "Knowledge increase," and "change in 337 risk perception and concern alleviation" were the main indicators for risk communications 338 conducted in a post-crisis period ( $83 \%, 50 \%$, respectively). There was over $15 \%$ difference in

339

340

341

342

343

344

345

346

347

348

349

350

351

352

353

354

355

356

357

358

359

360

361

362

363

364

365

366

367

368

369

370

371

372

"change in risk perception and concern alleviation" between risk communications targeting citizens/NPOs compared to risk communications targeting other groups ( $45 \%$ vs. $25 \%$ ). The same was observed for "change in risk perception and concern alleviation" and "decision making and behavior change" between risk communications conducted at an individual/small group level and risk communications conducted in larger groups ( $32 \%$ vs. $49 \%$ and $71 \%$ vs. $56 \%$, respectively).

The analyses (summarized in Table S3) revealed a significant association between study field and "trust building" $(P<0.05)$, between intervention timing and "change in risk perception and concern alleviation" $(P<0.05)$, between communication type and "change in risk perception and concern alleviation" $(P<0.05)$, and between communication type and "decision making and behavior change" $(P<0.05)$. Multiple comparisons did not find any significant difference between study fields in terms of "trust building."

\section{Discussion}

This study was implemented to obtain a comprehensive picture of recent risk communication practices across academic fields. Many established practices were taking place in the medical field, during a non-/pre-crisis period, targeting citizens/NPOs, and in the form of large group or mass communication. There are multiple possible explanations for the findings. First, the medical industry has a generally larger number of publications [50], and some medical issues, such as chronic diseases, are generally common or well-known problems. Second, there are naturally many more individuals who are at risk but not yet affected by certain threats (i.e., in the "non-/pre-crisis period"), compared with those who are already affected. Furthermore, communication that takes place during or shortly after the occurrence of an unexpected event is often called "crisis communication," as opposed to "risk communication" [27]. Finally, risk communication is a central tool employed to protect public health and safety [7,8]. It is understandable that the ultimate beneficiaries became the target population of many risk communication activities.

The communality in the use of increased knowledge, a change in risk perception, and behavior change as objectives and evaluation indicators of recent activities can be explained by the Health Belief Model [51-53] which was developed by social psychologists and is one of the most influential theoretical models. This model proposes that these three primary objectives are closely linked and that knowledge influences individual perceptions about risks and can guide people to perform recommended preventive behavior, which leads to better health outcomes. The

Peer) reviewing PDF | (2020:03:46457:1:0:NEW 26 Jun 2020) 
373 United States Food and Drug Administration also lists these three as central objectives of risk 374 communication [22]. The usefulness of addressing these domains is empirically supported by the

375 active application of this cognitive and behavioral model in various public health settings [54376 56].

377

378

379

380

381

382

383

384

385

386

387

388

389

390

391

392

393

394

395

396

397

398

399

400

401

402

403

404

405

406

407

408

409

410

411

Risk communication activities are taking diverse approaches correlating with varying objectives as discussed in the literature $[4,6,7,28]$; yet, this study suggests that there are some repeated patterns in the implementation. Risk communication activities that aim at changing risk perceptions of target audience and/or alleviating their concerns are likely to be conducted in the form of large group or mass communication. In contrast, risk communication activities that aim at supporting decision making and behavior change are likely to be conducted in the form of an individual/small group communication. This pattern corresponds with the finding of Edwards et al. [57]. They reviewed literature on risk communication in health care and found one-to-one communication to be highly effective in decision making and behavioral change because such communication is suitable to address individuals' circumstances, and their specific needs and concerns.

Some important gaps in current practices were revealed in this study. For example, the majority of the target audience of risk communication activities was identified as citizens or Non-Profit Organizations (NPOs). However, stakeholders concerning risk communication also include academics and professionals, governments, media, industries, individual producers, and emergency-response agencies [20,27]. It is critical that all stakeholders receive regular risk communication training to impart up-to-date knowledge about relevant risks and to foster and maintain their ability to engage in managing risks in a collaborative manner. The marginalization of the need to focus on reducing psychological distress and trust building in risk communication activities is another concern. The importance of cultivating trust relationships and addressing mental health components is well understood. However, past studies have pointed out challenges including differences between scientists and laypersons in technical knowledge, risk perceptions and access to information, as well as complex and severe social problems surrounding people who are at risk of or affected by crisis, such as poverty, displacement and loss of livelihoods $[5,13,58,59]$. This study indicates that further efforts are needed to address these challenges.

This study has several limitations. The chosen methodology for material search may have limited the investigation from discovering additional relevant materials, although this study used large search engines that cover a broad range of topics and the widely accepted term of "risk communication." In addition, relevant conference presentations, books and non-English materials were not included for review. The methodological appropriateness and validity of individual studies were not evaluated during the material selection process. There may have been studies whose quality of evidence was suboptimal. Lastly, because this study focused only on 
412 risk communication activities conducted in recent years, it did not evaluate in this paper how

413 they have changed over time, which limited the scope of the analysis.

414

415 In spite of the above limitations, this study makes a significant contribution to risk

416 communication research and provides some practical insights. For instance, the authors found

417 that "changes in risk perception and concern alleviation" are less focused upon during times of

418 crisis compared to other times. Additionally, "reduction in psychological distress" has been

419 neglected or not prioritized in risk communication activities. Yet, a large-scale and prolonged

420 crisis like the COVID-19 pandemic has demonstrated that long-lasting social isolation,

421 disruption of daily lives, and an uncertain end to a crisis will cause tremendous stress and

422 exhaustion. Some people may begin to feel ill or depressed, while other people may grow weary

423 of being extremely cautious [60-62]. Addressing psychological impacts such as these is vital and

424 should be part of the emergency response.

425

426 Suggested future work includes the investigation of the effectiveness of risk communication

427 activities across academic fields. It is critical to determine whether effectiveness differs based on

428 risk characteristics and risk communication objectives and approaches. To address the gaps in

429 recent practices, key lessons can be drawn from risk communication activities aimed at trust

430 building and reduction in psychological distress, as well as from risk communication targeting

431 non-citizen/NPO stakeholders. Future research can also explore how a crisis evolves and

432 determine its implications for risk communication activities. For instance, it is useful to assess

433 changes in the approach toward communication about COVID-19 along with the emergence and

434 spread of the disease, in consideration of its profound and diverse impacts on society and

435 individuals.

\section{Conclusion}

437 While risk communication has been implemented in a variety of ways for diverse objectives, this

438 study revealed some overall trends in the objectives, approaches and evaluation indicators

439 applied for recent risk communication activities. At the same time, the results of analysis also

440 suggest that there are some patterns in implementation; associations exist between the study field

441 and the communication type, and between the objectives/evaluation indicators and the

442 intervention timing and communication type. These facts may provide useful insights to those

443 who are involved in risk communication in designing and evaluating their activities. This study

444 also identified the limited attention in current practices to cultivating trust building and reduction

445 in psychological distress, as well as targeting non-citizen/NPO groups. Addressing these gaps is

446 an important way forward for a sustainable path toward effective risk management and better

447 resilience. 


\section{Acknowledgements}

449 This paper was prepared after the authors added analyses, results, and discussion to a report for 450 the Research on the Health Effects of Radiation organized by the Ministry of the Environment, 451 Japan (http://www.env.go.jp/chemi/chemi/rhm/R0104e_3.pdf). We thank our colleagues who are 452 in charge of other parts of the larger research project that encompasses this study. They provided 453 valuable input during the preparation and implementation of this study. The views discussed in 454 this paper are those of the authors and do not necessarily reflect the positions of those colleagues, 455 the affiliated institutions, or the funding agency.

\section{References}

457 1. World Health Organization. Coronavirus disease (COVID-19) advice for the public: Myth busters [Internet]. Geneva: World Health Organization [cited 2020 Jun 5]. Available from: https://www.who.int/emergencies/diseases/novel-coronavirus-2019/advice-for-public/mythbusters.

2. Shiloh Vidon T. Conspiracy theories and fake news: Fighting the Covid-19 'infodemic'. France 24 [Internet]. 2020 Apr 26 [cited 2020 Jun 5]. Available from: https://www.france24.com/en/20200426-conspiracy-theories-and-fake-news-fighting-thecovid-19-infodemic.

3. International Federation of Red Cross and Red Crescent Societies, United Nations Children's Fund, World Health Organization. COVID-19 global response: Risk communication and community engagement (RCCE) strategy. Geneva: International Federation of Red Cross and Red Crescent Societies, United Nations Children's Fund, World Health Organization; 2020.

4. National Research Council. Improving risk communication. Washington, DC: National Academies Press; 1989. doi: 10.17226/1189.

5. Fischhoff B. Risk perception and communication unplugged: Twenty years of process. Risk Anal. 1995; 15(2): 137-145.

6. Covello V, Sandman PM. Risk communication: Evolution and revolution. In: Wolbarst A, editor. Solutions to an environment in peril. Baltimore, MD: John Hopkins University Press; 2001. p. 164-178.

7. International Risk Governance Center. Introduction to the IRGC Risk Governance Framework, revised version. Lausanne: Ecole Polytechnique Fédérale de Lausanne, International Risk Governance Center; 2017.

8. Glik DC. Risk communication for public health emergencies. Annu Rev Public Health. 2007; 28: 33-54.

9. Lopez-Gonzalez AA, Aguilo A, Frontera M, Bennasar-Veny M, Campos I, Vicente-Herrero T, Tomas-Salva M, de Pedro-Gomex J, Tauler P. Effectiveness of the Heart Age tool for improving modifiable cardiovascular risk factors in a Southern European population: A 
485

486

487

488

489

490

491

492

493

494

495

496

497

498

499

500

501

502

503

504

505

506

507

508

509

510

511

512

513

514

515

516

517

518

519

520

521

522

523

randomized trial. Eur J Prev Cardiol. 2015; 22(3): 389-396. doi: $10.1177 / 2047487313518479$.

10. Tiozzo B, Mari S, Magaudda P, Arzenton V, Capozza D, Neresini F, Ravarotto L. Development and evaluation of a risk-communication campaign on salmonellosis. Food Control. 2011; 22(1): 109-117. doi: 10.1016/j.foodcont.2010.04.030.

11. MacDonald Gibson J, Rowe A, Stone ER, Bruine de Bruin W. Communicating quantitative information about unexploded ordnance risks to the public. Environ Sci Technol. 2013; 47: 4004-4013. doi: 10.1021/es305254j.

12. Renn O, Kastenholz H. Annex I: "State of the art" report on risk communication. Risk communication for chemical product risks: An OECD background paper. Berlin: Bundesinstitut für gesundheitlichen Verbraucherschutz und Veterinärmedizin; 2000.

13. Covello VT, von Winterfeldt D, Slovic P. Risk communication: A review of the literature. Risk Abstracts. 1986; 3: 171-182.

14. European Chemicals Agency. Guidance on the communication of information on the risks and safe use of chemicals. Helsinki: European Chemicals Agency; 2010.

15. United States Environmental Protection Agency. Risk communication [Internet]. Washington, DC: United States Environmental Protection Agency [cited 2019 Nov 12]. Available from: https:/www.epa.gov/risk/risk-communication.

16. Ministry of the Environment Japan. Jichitai no tame no kagaku-busshitsu ni kansuru risukukomyunikēshon manyuaru (Manual for risk communication concerning chemical substances in municipalities) (partial revisions in Mar 2011). Tokyo: Ministry of the Environment Japan; 2002. Japanese.

17. Chemical Society of Japan. Kagaku-busshitsu Risukukomyunikēshon shuhou kentou chyousa houkokushyo (Report on risk communication techniques concerning chemical substances). Tokyo: Ministry of the Environment Japan; 2001. Japanese.

18. Food and Agriculture Organization of the United Nations, World Health Organization. The application of risk communication to food standards and safety matters, FAO Food and Nutrition Paper 70. Rome: Food and Agriculture Organization of the United Nations and World Health Organization; 1998.

19. Food and Agriculture Organization of the United Nations, World Health Organization. Risk communication applied to food safety handbook. Rome: Food and Agriculture Organization of the United Nations and World Health Organization; 2016.

20. Codex Alimentarius Commission, Joint Food and Agriculture Organization of the United Nations/World Health Organization Food Standards Programme. Codex Alimentarius Commission Procedural Manual. 26 ${ }^{\text {th }}$ ed. Rome: Food and Agriculture Organization of the United Nations and World Health Organization; 2018.

21. European Food Safety Authority. When food is cooking up a storm: Proven recipes for risk communications. $3^{\text {rd }}$ ed. Parma: European Food Safety Authority; 2017. doi: $10.2805 / 119491$. 
524

525

526

527

528

529

530

531

532

533

534

535

536

537

538

539

540

541

542

543

544

545

546

547

548

549

550

551

552

553

554

555

556

557

558

559

560

561

562

22. United States Department of Health and Human Services, Food and Drug Administration. Communicating risks and benefits: An evidence-based user's guide. Fischhoff B, Brewer NT, Downs JS, editors. Silver Spring, MD: United States Department of Health and Human Services, Food and Drug Administration; 2011.

23. United States Department of Health and Human Services, Food and Drug Administration. Strategic plan for risk communication [Internet]. Silver Spring, MD: United States Department of Health and Human Services, Food and Drug Administration [updated 2012; cited 2019 Nov 11]. Available from: https://www.fda.gov/about-fda/reports/strategic-planrisk-communication.

24. Gamhewage G. An introduction to risk communication [Internet]. Geneva: World Health Organization; 2014 [cited 2020 Jun 20]. Available from: https://www.who.int/publications/i/item/an-introduction-to-risk-communication.

25. World Health Organization. Risk communication: General information on risk communication [Internet]. Geneva: World Health Organization [cited 2019 Nov 11]. Available from: https://www.who.int/risk-communication/background/en/.

26. Persensky J, Browde S, Szabo A, Peterson L, Specht E, Wight E. Effective risk communication: The Nuclear Regulatory Commission's guidelines for external risk communication. Washington, DC: United States Nuclear Regulatory Commission; 2004.

27. United States Department of Health and Human Services, Centers for Disease Control and Prevention. Crisis and emergency risk communication (CERC) (2018 update). Atlanta, GA: United States Department of Health and Human Services, Centers for Disease Control and Prevention; 2018.

28. Lundgren RE, McMakin AH. Risk communication: A handbook for communicating environmental, safety, and health risks. 5th ed. Piscataway, NJ: Wiley-IEEE Press; 2013.

29. Zipkin DA, Umscheid CA, Keating NL, Allen E, Aung K, Beyth R, Kaatz S, Mann DM, Sussman JB, Korenstein D, Schardt C, Nagi A, Sloane R. Feldstein DA. Evidence-based risk communication: A systematic review. Ann Intern Med. 2014; 161: 270-280. doi: 10.7326/M14-0295.

30. Stewart MA. Effective physician-patient communication and health outcomes: A review. Can Med Assoc J. 1995; 152: 1423-1433.

31. Coombs WT. Ongoing crisis communication: Planning, managing and responding. 3rd ed. Thousand Oaks, CA: SAGE; 2012.

32. Coombs WT. Crisis management and communications [Internet]. Gainesville, FL: Institute for Public Relations; 2007 [cited 2019 Nov 8]. Available from: https://instituteforpr.org/crisis-management-and-communications/.

33. Aoki S. Hiritsu no sa no tajyu-hikaku (pairwise.prop.test no kakuchyou) (Multiple comparisons of proportions: An extension of the pairwise.prop.test) [updated 2010 Jan 5; cited 2019 Nov 8]. Available from: http://aoki2.si.gunma-u.ac.jp/R/p_multi_comp2.html. Japanese. 
563

564

565

566

567

568

569

570

571

572

573

574

575

576

577

578

579

580

581

582

583

584

585

586

587

588

589

590

591

592

593

594

595

596

597

598

599

600

34. R Development Core Team. R: A language and environment for statistical computing. Vienna: R Foundation for Statistical Computing; 2008.

35. Lu H, Siemer WF, Baumer MS, Decker DJ. Exploring the role of gain versus loss framing and point of reference in messages to reduce human-bear conflicts. Soc Sci J. 2018; 55: 182-192. doi: 10.1016/j.soscij.2017.05.002.

36. Feenstra H, Ruiter RAC, Kok G. Evaluating traffic informers: Testing the behavioral and social-cognitive effects of an adolescent bicycle safety education program. Accid Anal Prev. 2014; 73: 288-295. doi: 10.1016/j.aap.2014.09.024.

37. Wu A, Weseley AJ. The effects of statistical format and population specificity on adolescent perceptions of cell phone use while driving. Curr Psychol. 2013; 32: 32-43. doi: 10.1007/s12144-012-9161-2.

38. Dawson IGJ, Johnson JEV, Luke MA. One too many? Understanding the influence of risk factor quantity on perceptions of risk. Risk Anal. 2017; 37(6): 1157-1169. doi: 10.1111/risa.12690.

39. Poortvliet PM, Lokhorst AM. The key role of experiential uncertainty when dealing with risks: Its relationships with demand for regulation and institutional trust. Risk Anal. 2016; 36(8): 1615-1629. doi: 10.1111/risa.12543.

40. Brown SM, Culver JO, Osann KE, MacDonald DJ, Sand S, Thornton AA, Grant M, Bowen DJ, Metcalfe KA, Burke HB, Robson ME, Friedman S, Weitzel JN. Health literacy, numeracy, and interpretation of graphical breast cancer risk estimates. Patient Educ Couns. 2011; 83(1): 92-98. doi: 10.1016/j.pec.2010.04.027.

41. Moussaïd M, Brighton H, Gaissmaier W. The amplification of risk in experimental diffusion chains. Proc Natl Acad Sci. 2015; 112(18): 5631-5636. doi: 10.1073/pnas. 1421883112.

42. Garcia-Retamero R, Cokely ET. Effective communication of risks to young adults: Using message framing and visual aids to increase condom use and STD screening. J Exp Psychol Appl. 2011; 17(3): 270-287. doi: 10.1037/a0023677.

43. Nan X, Dahlstrom MF, Richards A, Rangarajan S. Influence of evidence type and narrative type on HPV risk perception and intention to obtain the HPV vaccine. Health Commun. 2015; 30: 301-308. doi: 10.1080/10410236.2014.888629.

44. Binder AR, Scheufele DA, Brossard D, Gunther AC. Interpersonal amplification of risk? Citizen discussions and their impact on perceptions of risks and benefits of a biological research facility. Risk Anal. 2011; 31(2): 324-334. doi: 10.1111/j.1539-6924.2010.01516.x.

45. Henneman L, Oosterwijk JC, van Asperen CJ, Menko FH, Ockhuysen-Vermey CF, Kostense PJ, Claassen L, Timmermans DRM. The effectiveness of a graphical presentation in addition to a frequency format in the context of familial breast cancer risk communication: A multicenter controlled trial. BMC Med Inform Decis Mak. 2013; 13: 55. doi: 10.1186/1472-6947-13-55. 
601

602

603

604

605

606

607

608

609

610

611

612

613

614

615

616

617

618

619

620

621

622

623

624

625

626

627

628

629

630

631

632

633

634

635

636

637

638

639

46. Besser SJ, Anderson JE, Weinman J. How do osteoporosis patients perceive their illness and treatment? Implications for clinical practice. Arch Osteoporos. 2012; 7: 115-124. doi: 10.1007/s11657-012-0089-9.

47. Cronin K, Midgley G, Jackson LS. Issues Mapping: A problem structuring method for addressing science and technology conflicts. Eur J Oper Res. 2014; 233: 145-158. doi: 10.1016/j.ejor.2013.08.012.

48. Rabinovich A, Morton TA. Unquestioned answers or unanswered questions: Beliefs about science guide responses to uncertainty in climate change risk communication. Risk Anal. 2012; 32(6): 992-1002. doi: 10.1111/j.1539-6924.2012.01771.x.

49. Harris AL, Sutherland MA, Hutchinson MK. Parental influences of sexual risk among urban African American adolescent males. J Nurs Scholarsh. 2013; 45(2): 141-150. doi: 10.1111/jnu. 12016.

50. Piro FN, Aksnes DW, Rørstad K. A macro analysis of productivity differences across fields: Challenges in the measurement of scientific publishing. J Am Soc Inf Sci Technol. 2013; 64(2): 307-320.

51. Hochbaum GM. Public participation in medical screening programs: A socio-psychological study. Washington, DC: United States Department of Health, Education, and Welfare; 1958.

52. Rosenstock IM. Historical origins of the Health Belief Model. Health Educ Monogr. 1974; 2(4): 328-335.

53. Rosenstock IM. The Health Belief Model and preventive health behavior. Health Educ Monogr. 1974; 2(4): 354-386.

54. Sharifirad G, Entezari MH, Kamran A, Azadbakht L. The effectiveness of nutritional education on the knowledge of diabetic patients using the Health Belief Model. J Res Med Sci. 2009; 14(1): 1-6.

55. Tola HH, Shojaeizadeh D, Tol A, Garmaroudi G, Yekaninejad MS, Kebede A, Ejeta LT, Kassa D, Klinkenberg E. Psychological and educational intervention to improve tuberculosis treatment adherence in Ethiopia based on Health Belief Model: A cluster randomized control trial. PLoS ONE. 2016; 11(5): e0155147. doi: 10.1371/journal.pone.0155147.

56. Ghaffari M, Tavassoli E, Esmaillzadeh A, Hassanzadeh A. Effect of Health Belief Model based intervention on promoting nutritional behaviors about osteoporosis prevention among students of female middle schools in Isfahan, Iran. J Educ Health Promot. 2012; 1: 14. doi: 10.4103/2277-9531.98572.

57. Edwards A, Hood K, Matthews E, Russell D, Russell I, Barker J, Bloor M, Burnard P, Covey J, Pill R, Wilkinson C, Stott N. The effectiveness of one-to-one risk communication interventions in health care: A systematic review. Med Decis Making. 2000; 20(3): 290297.

58. Renn O, Webler T, Johnson BB. Public participation in hazard management: The use of citizen panels in the U.S. RISK: Issues in Health \& Safety. 1991; 2(3):197-226. 
640

641

642

643

644

645

646

647

648

649

650

651

652

653

654

\section{5}

656

657

658

659

660

59. World Health Organization. Mental health in emergencies [Internet]. Geneva: World Health Organization [cited 2020 Jun 6]. Available from: https://www.who.int/news-room/factsheets/detail/mental-health-in-emergencies.

60. Rogers JP, Chesney E, Oliver D, Pollak TA, McGuire P, Fusar-Poli P, Zandi MS, Lewis G, Davis AS. Psychiatric and neuropsychiatric presentations associated with severe coronavirus infections: A systematic review and meta-analysis with comparison to the COVID-19 pandemic. Lancet Psychiatry. 2020; 7(7): 611-627. doi: 10.1016/S22150366(20)30203-0.

61. United States Department of Health and Human Services, Centers for Disease Control and Prevention. Coronavirus disease 2019 (COVID-19): Coping with stress [Internet]. Atlanta, GA: United States Department of Health and Human Services, Centers for Disease Control and Prevention [cited 2020 Jun 6]. Available from: https://www.cdc.gov/coronavirus/2019ncov/daily-life-coping/managing-stress-anxiety.html.

62. Brewer K. Coronavirus: How to protect your mental health. BBC News [Internet]. 2020 Mar 16 [cited 2020 Jun 6]. Available from: https://www.bbc.com/news/health-5187379.

\section{Supplemental Information Captions}

Table S1. Data extracted from selected articles.

Table S2. Results of statistical analyses on the association of study field with intervention timing, target audience, and communication type $(N=220)$.

Table S3. Results of statistical analyses on the association of objective/evaluation indicator with study field, intervention timing, target audience, and communication type.

Peer) reviewing PDF | (2020:03:46457:1:0:NEW 26 Jun 2020) 
Figure 1

Flow diagram of material selection.

$J R R=$ Journal of Risk Research 


\section{<English search engine> \\ PubMed 2,127 \\ PsycINFO 918 \\ ScienceDirect 513 \\ JRR 152 \\ Total: 3,710}

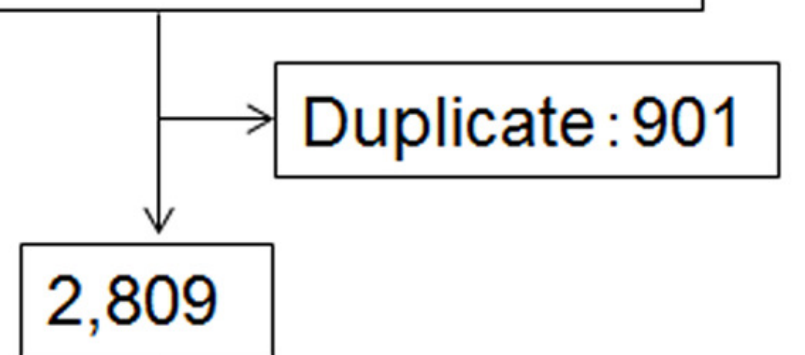

Abstract: 131/Language: 86

2,592
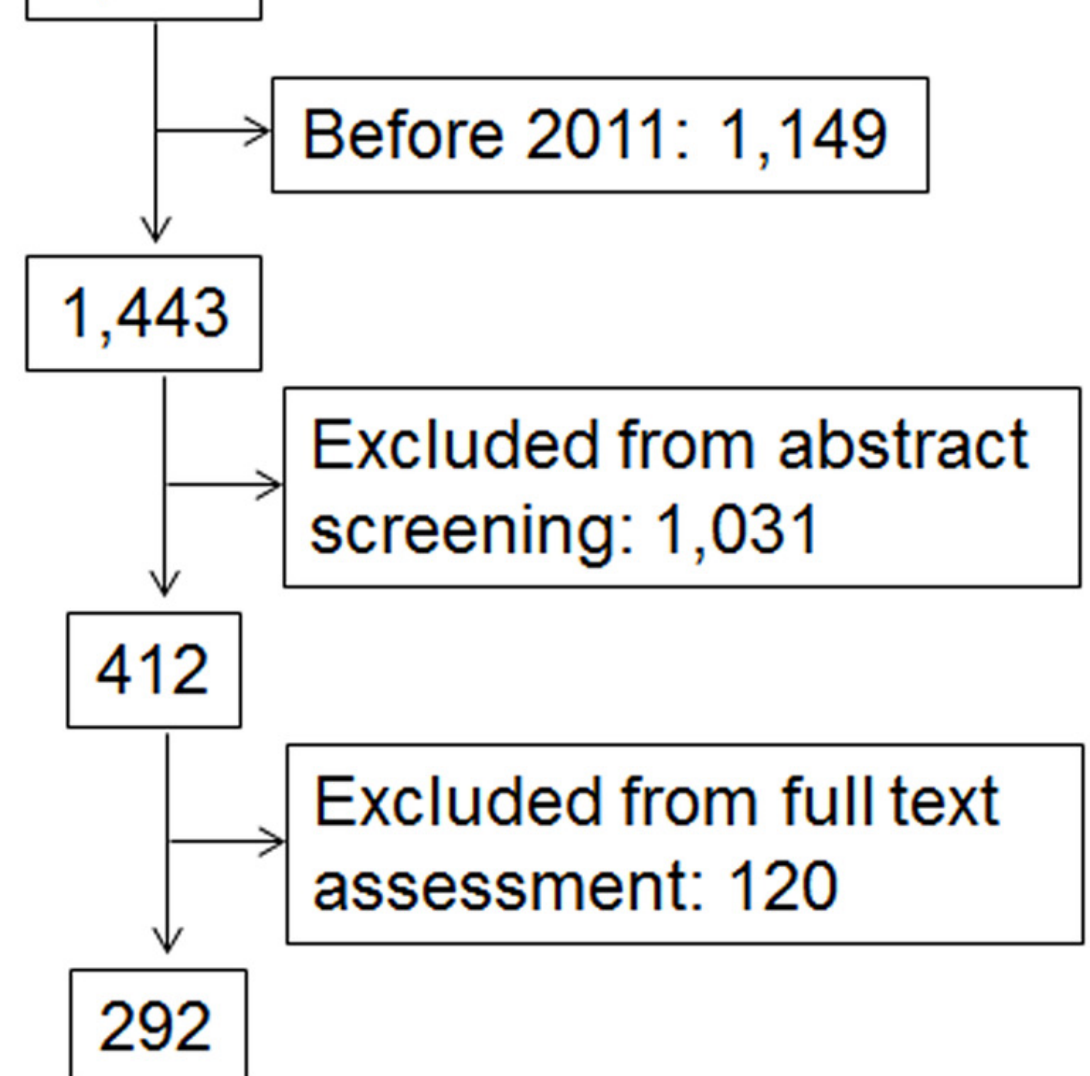
Figure 2

Descriptive statistics of the study variables $(N=292)$.

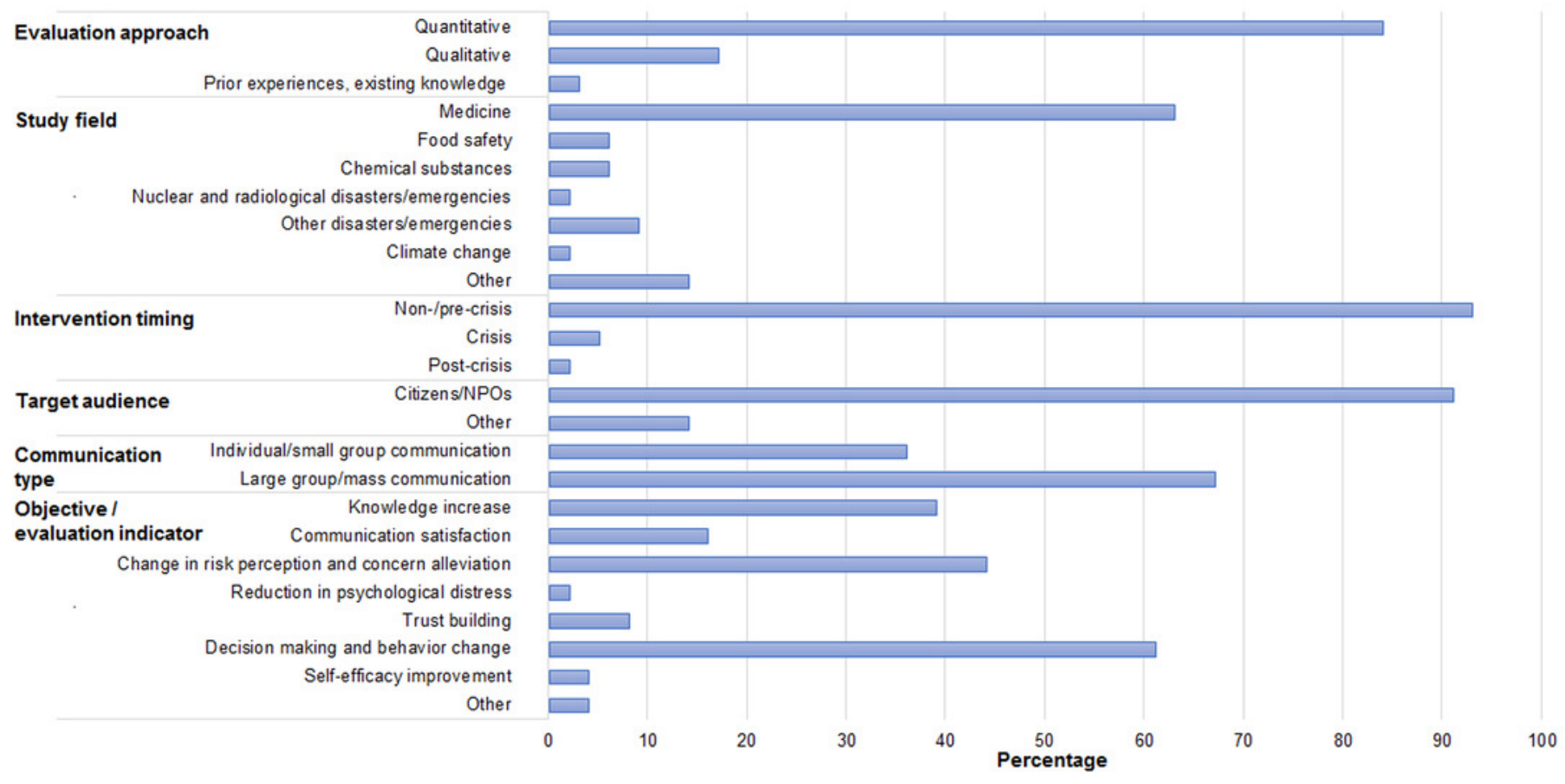




\section{Table 1 (on next page)}

Definitions and purposes of risk communication as stated by select international and national organizations. 
1 Table 1. Definitions and purposes of risk communication as stated by select international and national organizations.

\begin{tabular}{|c|c|c|c|c|c|c|c|c|c|c|}
\hline \multirow[t]{2}{*}{ Field } & \multirow[t]{2}{*}{ Organization } & \multirow[t]{2}{*}{ Definition } & \multirow[t]{2}{*}{ Purpose } & \multicolumn{7}{|c|}{$\begin{array}{l}\text { Extracted main purposes } \\
\text { of risk communication }\end{array}$} \\
\hline & & & & 1 & 2 & 3 & 4 & 5 & 6 & 7 \\
\hline \multirow[t]{2}{*}{$\begin{array}{l}\text { Chemical } \\
\text { substances }\end{array}$} & $\begin{array}{l}\text { Organization for } \\
\text { Economic Co- } \\
\text { operation and } \\
\text { Development [12] } \\
\text { (cited Covello } \\
\text { et al. [13]) }\end{array}$ & $\begin{array}{l}\text { The act of } \frac{\text { conveying or }}{\text { information }} \\
\text { transmitting } \\
\text { between interested parties } \\
\text { about (a) levels of health or } \\
\text { environmental risks; (b) the } \\
\text { significance or meaning of } \\
\text { health or environmental } \\
\text { risks; or (c) decisions, } \\
\text { actions, or policies aimed at } \\
\text { managing or controlling } \\
\text { health or environmental } \\
\text { risks. }\end{array}$ & & $\checkmark$ & & & & & & \\
\hline & $\begin{array}{l}\text { European Chemicals } \\
\text { Agency [14] }\end{array}$ & & $\begin{array}{l}\text { Helping to build trust among } \\
\text { organizations that risks are being } \\
\text { adequately assessed and managed; } \\
\text { assisting with making better } \\
\text { decisions on how to address risks; } \\
\text { helping to ensure smoother } \\
\text { implementation of risk } \\
\text { management policies; helping to } \\
\text { empower and reassure the general } \\
\text { public; helping to bridge the gap } \\
\text { between real risks and perceived } \\
\text { risks; and helping to prevent crises } \\
\text { from developing and managing } \\
\text { them when they do occur. }\end{array}$ & $\checkmark$ & & $\checkmark$ & & $\checkmark$ & $\checkmark$ & \\
\hline
\end{tabular}




\begin{tabular}{|c|c|c|c|c|c|}
\hline $\begin{array}{l}\text { United States } \\
\text { Environmental } \\
\text { Protection Agency [15] }\end{array}$ & $\begin{array}{l}\text { The process of informing } \\
\text { people about potential } \\
\text { hazards to their person, } \\
\text { property, or community. }\end{array}$ & $\begin{array}{l}\text { To help residents of affected } \\
\text { communities understand the } \\
\text { processes of risk assessment and } \\
\text { management, to form scientifically } \\
\text { valid perceptions of the likely } \\
\text { hazards, and to participate in } \\
\text { making decisions about how risk } \\
\text { should be managed. }\end{array}$ & $\checkmark$ & $\checkmark$ & \\
\hline $\begin{array}{l}\text { Ministry of the } \\
\text { Environment, } \\
\text { Japan }^{b}[16] \text { (cited the } \\
\text { Chemical Society of } \\
\text { Japan [17]) }\end{array}$ & $\begin{array}{l}\text { Sharing } \\
\text { information and exchanging } \\
\text { opinions between citizens, } \\
\text { industry, government, and } \\
\text { other interested parties on } \\
\text { health and environmental } \\
\text { risks related to chemical } \\
\text { substances. }\end{array}$ & $\begin{array}{l}\text { To increase awareness and } \\
\text { understanding of the relevant risk } \\
\text { and its management and to build a } \\
\text { trust relationship among all } \\
\text { concerned stakeholders, and reduce } \\
\text { the risk through demanding and } \\
\text { providing information and } \\
\text { exchanging opinions between } \\
\text { stakeholders. }\end{array}$ & $\checkmark$ & $\checkmark$ & $\checkmark$ \\
\hline
\end{tabular}




\begin{tabular}{|c|c|c|c|c|c|c|c|}
\hline Food safety & $\begin{array}{l}\text { Food and Agriculture } \\
\text { Organization of the } \\
\text { United Nations and } \\
\text { World Health } \\
\text { Organization }[18,19] \\
\\
\\
\text { Codex Alimentarius } \\
\text { Commission }[20]\end{array}$ & $\begin{array}{l}\text { The exchange of } \\
\text { information and opinions } \\
\text { concerning risk and risk- } \\
\text { related factors among risk } \\
\text { assessors, risk managers, } \\
\text { consumers and other } \\
\text { interested parties. } \\
\text { The interactive exchange of } \\
\text { information and opinions } \\
\text { throughout the risk analysis } \\
\text { process concerning risk, } \\
\text { risk-related factors and risk } \\
\text { perceptions, among risk } \\
\text { assessors, risk managers, } \\
\text { consumers, industry, the } \\
\text { academic community and } \\
\text { other interested parties, } \\
\text { including the explanation of } \\
\text { risk assessment findings } \\
\text { and the basis of risk } \\
\text { management decisions. }\end{array}$ & $\begin{array}{l}\text { To enable people to protect their } \\
\text { health from food safety risks by } \\
\text { providing information that enables } \\
\text { them to make informed food safety } \\
\text { decisions, to facilitate dialogue and } \\
\text { understanding among all interested } \\
\text { stakeholders, and to improve the } \\
\text { overall effectiveness of the risk } \\
\text { analysis process. } \\
\text { Risk communication should: (i) } \\
\text { promote awareness and } \\
\text { understanding of the specific issues } \\
\text { under consideration during the risk } \\
\text { analysis; (ii) promote consistency } \\
\text { and transparency in formulating } \\
\text { risk management } \\
\text { options/recommendations; (iii) } \\
\text { provide a sound basis for } \\
\text { understanding the risk management } \\
\text { decisions proposed; (iv) improve } \\
\text { the overall effectiveness and } \\
\text { efficiency of the risk analysis; (v) } \\
\text { strengthen the working } \\
\text { relationships among participants; } \\
\text { (vi) foster public understanding of } \\
\text { the process, so as to enhance trust } \\
\text { and confidence in the safety of the } \\
\text { food supply; (vii) promote the } \\
\text { appropriate involvement of all } \\
\text { interested parties; and (viii) } \\
\text { exchange information in relation to } \\
\text { the concerns of interested parties } \\
\text { about the risks associated with } \\
\text { food. }\end{array}$ & $\checkmark$ & $\checkmark$ & $\checkmark$ & $\checkmark$ \\
\hline
\end{tabular}




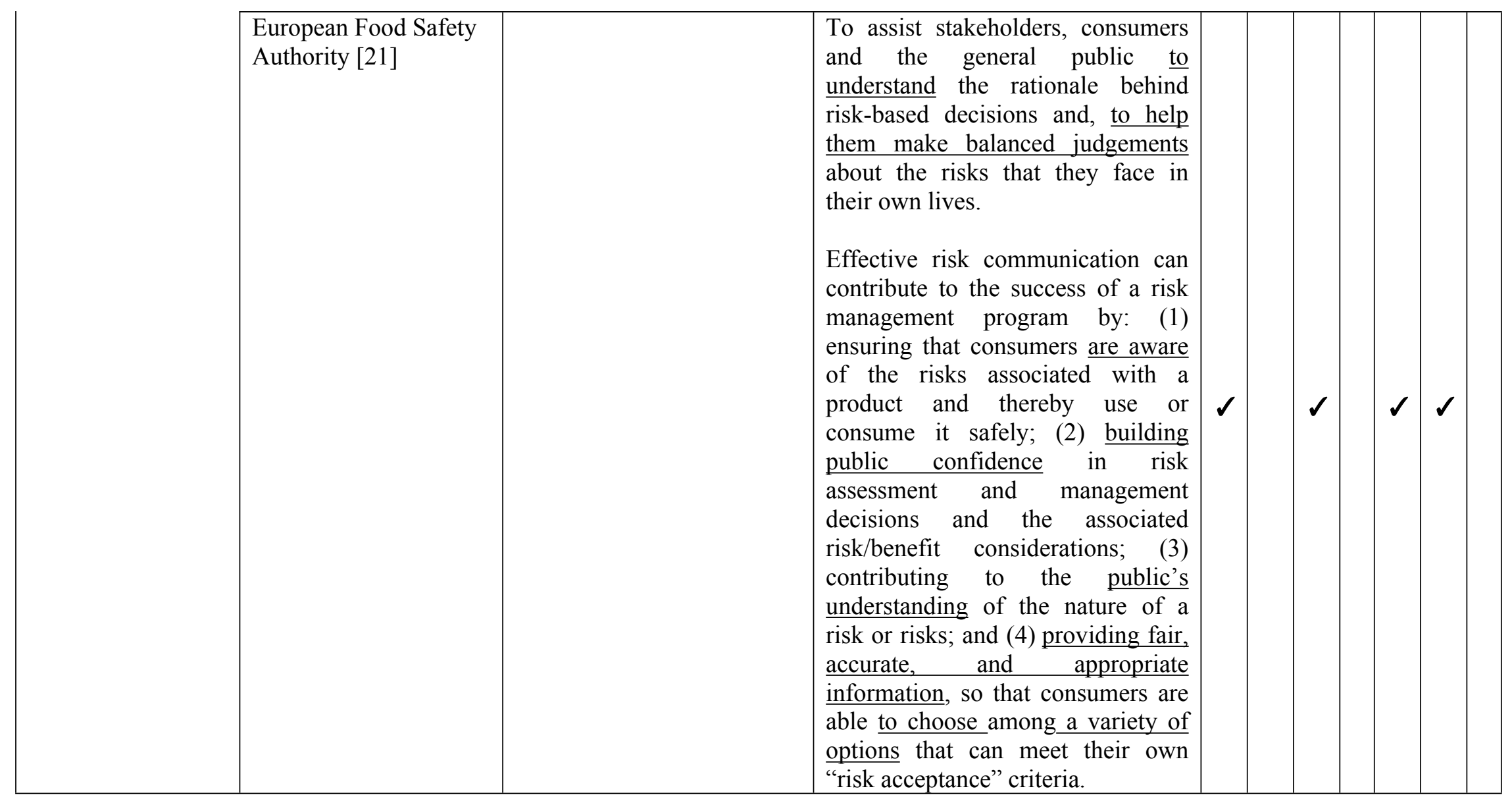




\begin{tabular}{|c|c|c|c|c|c|c|c|c|}
\hline $\begin{array}{l}\text { Food safety \& } \\
\text { medicine }\end{array}$ & $\begin{array}{l}\text { United States Food and } \\
\text { Drug Administration } \\
{[22,23]}\end{array}$ & $\begin{array}{l}\text { Risk communication } \\
\text { activities fall into two broad } \\
\text { categories: (1) interactively } \\
\text { sharing risk and benefit } \\
\text { information to enable } \\
\text { people to make informed } \\
\text { judgments about use of } \\
\text { FDA-regulated products } \\
\text { and (2) providing guidance } \\
\text { to relevant industries about } \\
\text { how they can most } \\
\text { effectively communicate the } \\
\text { risks and benefits of } \\
\text { regulated products. }\end{array}$ & $\begin{array}{l}\text { Share information, change beliefs, } \\
\text { change behavior. } \\
\text { (Examples listed as intermediate } \\
\text { outcomes that can lead to the } \\
\text { improvement of overall public } \\
\text { health are as follows:) (1) improved } \\
\text { understanding of the risks and } \\
\text { benefits of regulated products by } \\
\text { the multiple audiences with whom } \\
\text { FDA communicates, including } \\
\text { relevant international audiences; (2) } \\
\text { increased public awareness of crisis } \\
\text { events and the increased likelihood } \\
\text { that affected individuals or groups } \\
\text { will take recommended actions; (3) } \\
\text { increased public satisfaction with } \\
\text { FDA as an expert and credible } \\
\text { source of information about } \\
\text { regulated products; and } \\
\text { (4) increased confidence that target } \\
\text { audiences are getting useful, timely } \\
\text { information as it becomes } \\
\text { available, to help them make } \\
\text { informed choices. }\end{array}$ & $\checkmark$ & $\checkmark$ & $\checkmark$ & $\checkmark$ & $\checkmark$ \\
\hline $\begin{array}{l}\text { Medicine } \\
\text { disasters }\end{array}$ & $\begin{array}{l}\text { World Health } \\
\text { Organization }[24,25]\end{array}$ & $\begin{array}{l}\text { The two-way and multi- } \\
\text { directional communications } \\
\text { and engagement with } \\
\text { affected populations. } \\
\text { The exchange of real-time } \\
\text { information, advice and } \\
\text { opinions between experts } \\
\text { and people facing threats to } \\
\text { their health, economic or } \\
\text { social well-being. }\end{array}$ & $\begin{array}{l}\text { To share information vital for } \\
\text { saving life, protecting health and } \\
\text { minimizing harm to self and others; } \\
\text { to change beliefs; and/or to change } \\
\text { behavior. } \\
\text { To enable people at risk to take } \\
\text { informed decisions to protect } \\
\text { themselves and their loved ones. }\end{array}$ & $\checkmark$ & & $\checkmark$ & & $\checkmark$ \\
\hline
\end{tabular}




\begin{tabular}{|c|c|c|c|c|c|c|}
\hline $\begin{array}{l}\text { United States Nuclear } \\
\text { Regulatory } \\
\text { Commission [26] }\end{array}$ & $\begin{array}{l}\text { An interactive process used } \\
\text { in talking or writing about } \\
\text { topics that cause concern } \\
\text { about health, safety, } \\
\begin{array}{l}\text { security, or the } \\
\text { environment. }\end{array}\end{array}$ & $\begin{array}{l}\text { (Examples listed:) (1) providing } \\
\text { information to the public about } \\
\text { numerous issues, including } \\
\text { inspection findings and their } \\
\text { significance, changes to regulatory } \\
\text { requirements, security and } \\
\text { safeguards issues, or how the } \\
\text { decision-making process works; (2) } \\
\text { to learn about stakeholder concerns, } \\
\text { perceptions about risks, } \\
\text { expectations about involvement in } \\
\text { risk management decisions, or local } \\
\text { information that will assist in risk } \\
\text { analysis; (3) building/restoring trust } \\
\text { and relationships; (4) to ask } \\
\text { stakeholders for input in a decision- } \\
\text { making process; } \\
\text { (5) influencing people's behavior } \\
\text { and perceptions about risk. }\end{array}$ & $\checkmark$ & $\checkmark$ & $\checkmark$ & $\checkmark$ \\
\hline $\begin{array}{l}\text { United States Centers } \\
\text { for Disease Control } \\
\text { and Prevention [27] }\end{array}$ & $\begin{array}{l}\text { Risk communication } \\
\text { provides the community } \\
\text { with information about the } \\
\text { specific type (good or bad) } \\
\text { and magnitude (strong or } \\
\text { weak) of an outcome from } \\
\text { an exposure or behavior. } \\
\text { Typically, risk } \\
\text { communication is a } \\
\text { discussion of a negative } \\
\text { outcome and the probability } \\
\text { that the outcomes will } \\
\text { occur. }\end{array}$ & $\begin{array}{l}\text { Risk communication can be } \\
\text { employed to help an individual } \\
\text { make a choice about a behavior } \\
\text { such as smoking, getting } \\
\text { vaccinated, or undergoing a } \\
\text { medical treatment. }\end{array}$ & $\checkmark$ & & & $\checkmark$ \\
\hline
\end{tabular}

$3{ }^{a} 1=$ knowledge increase, $2=$ communication satisfaction, $3=$ change in risk perception and concern alleviation, $4=$ reduction in psychological 4 distress, 5 = trust building, $6=$ decision making and behavior change, $7=$ self-efficacy improvement.

$5 \quad{ }^{b}$ Translated by an author of this article (AS). 
Table 2 (on next page)

Evaluation examples from risk communication studies. 
Table 2. Evaluation examples from risk communication studies.

\begin{tabular}{|c|c|c|c|c|}
\hline Indicator & $\begin{array}{l}\text { Author(s), } \\
\text { year of } \\
\text { publication }\end{array}$ & Study field & Study description & Example(s) \\
\hline \multirow[t]{2}{*}{$\begin{array}{l}\text { Knowledge } \\
\text { increase }\end{array}$} & $\begin{array}{l}\text { Brown } \\
\text { et al., } \\
2011[40]\end{array}$ & Medicine & $\begin{array}{l}\text { This study assessed the relationships between } \\
\text { health literacy, numeracy, and the ability to } \\
\text { interpret graphs. Participants were asked to } \\
\text { interpret different types of graphs in the context } \\
\text { of breast cancer risk and make hypothetical } \\
\text { treatment decisions. }\end{array}$ & $\begin{array}{l}\text { Interpreting the risk of a new breast cancer } \\
\text { occurring in the other breast following } \\
\text { preventive surgical options based on the } \\
\text { hypothetical information from the provided } \\
\text { graphs, making a surgical option, and } \\
\text { describing differences in remaining risk } \\
\text { between surgical options. }\end{array}$ \\
\hline & $\begin{array}{l}\text { Moussaïd } \\
\text { et al., } \\
2015[41]\end{array}$ & $\begin{array}{l}\text { Chemical } \\
\text { substances }\end{array}$ & $\begin{array}{l}\text { This study analyzed social transmission of risk } \\
\text { information by examining how messages on the } \\
\text { risk of a controversial antibacterial agent } \\
\text { changed when being passed from one person to } \\
\text { another in a chain of up to } 10 \text { persons. }\end{array}$ & $\begin{array}{l}\text { Information diversions and defects occurred } \\
\text { while being transferred from one person to } \\
\text { the next. }\end{array}$ \\
\hline \multirow[t]{2}{*}{$\begin{array}{l}\text { Communication } \\
\text { satisfaction }\end{array}$} & $\begin{array}{l}\text { Garcia- } \\
\text { Retamero } \\
\text { et al., } \\
2011 \text { [42] }\end{array}$ & Medicine & $\begin{array}{l}\text { This study evaluated the effectiveness of gain- } \\
\text { and loss-framed messages and visual aids about } \\
\text { sexually transmitted diseases (STDs) on } \\
\text { participants' reactions to intervention material } \\
\text { and their STD-related risk perception, attitude, } \\
\text { behavioral intention, and behaviors. }\end{array}$ & $\begin{array}{l}\text { Participants' evaluation on how interesting, } \\
\text { involving, and informative the intervention } \\
\text { material was. }\end{array}$ \\
\hline & $\begin{array}{l}\text { Tiozzo } \\
\text { et al., } \\
2011[10]\end{array}$ & Food safety & $\begin{array}{l}\text { This study evaluated the effectiveness of a } \\
\text { campaign on salmonellosis on public risk } \\
\text { awareness and knowledge on risk and } \\
\text { prevention behavior. }\end{array}$ & $\begin{array}{l}\text { Participants' evaluation of the usefulness of } \\
\text { the campaign material. }\end{array}$ \\
\hline \multirow{2}{*}{$\begin{array}{l}\text { Change in risk } \\
\text { perception and } \\
\text { concern } \\
\text { alleviation }\end{array}$} & $\begin{array}{l}\text { Nan et al., } \\
2015[43]\end{array}$ & Medicine & $\begin{array}{l}\text { This study investigated the impact of evidence- } \\
\text { oriented messages and narrative-type messages } \\
\text { about human papillomavirus (HPV) on } \\
\text { recipients' risk perception and vaccination } \\
\text { intentions. }\end{array}$ & $\begin{array}{l}\text { Participants' perceived susceptibility to } \\
\text { HPV. }\end{array}$ \\
\hline & $\begin{array}{l}\text { Binder } \\
\text { et al., } \\
2011[44]\end{array}$ & $\begin{array}{l}\text { Other } \\
\text { disasters/ } \\
\text { emergencies }\end{array}$ & $\begin{array}{l}\text { This study analyzed the influence of } \\
\text { interpersonal discussions on residents' } \\
\text { perceptions about the risks and benefits of the } \\
\text { planned US National Bio- and Agro-Defense } \\
\text { Facility. }\end{array}$ & $\begin{array}{l}\text { Residents' perceived risk of negative impacts } \\
\text { associated with the facility on their safety, } \\
\text { health, and the environment. }\end{array}$ \\
\hline
\end{tabular}




\begin{tabular}{|c|c|c|c|c|}
\hline \multirow{2}{*}{$\begin{array}{l}\text { Reduction in } \\
\text { psychological } \\
\text { distress }\end{array}$} & $\begin{array}{l}\text { Henneman } \\
\text { et al., } \\
2013 \text { [45] }\end{array}$ & Medicine & $\begin{array}{l}\text { This study assessed the effects of the provision } \\
\text { of graphs in addition to frequency information } \\
\text { about breast cancer on at-risk women's risk } \\
\text { understanding, psychological wellbeing, and } \\
\text { intention to have breast screening. }\end{array}$ & $\begin{array}{l}\text { Psychological wellbeing measured by an } \\
\text { adapted version of the Lerman Cancer Worry } \\
\text { Scale (CWS) and the Dutch version of the } \\
\text { six-item version of the state scale of the } \\
\text { Spielberger State-Trait Anxiety Inventory. }\end{array}$ \\
\hline & $\begin{array}{l}\text { MacDonald } \\
\text { Gibson } \\
\text { et al., } \\
2013[11]\end{array}$ & $\begin{array}{l}\text { Chemical } \\
\text { substances }\end{array}$ & $\begin{array}{l}\text { This study explored how probabilistic } \\
\text { information influences risk understanding, } \\
\text { opinions regarding risk/site management, risk } \\
\text { perception, and concerns of residents who live } \\
\text { nearby a closed site contaminated with } \\
\text { unexploded ordnance. }\end{array}$ & $\begin{array}{l}\text { Negative emotional reactions to the provided } \\
\text { information: "How (worried, afraid, anxious) } \\
\text { would you be about (getting hurt if you } \\
\text { worked at the site, letting children play near } \\
\text { the site, living near the site)?" }\end{array}$ \\
\hline \multirow[b]{2}{*}{ Trust building } & $\begin{array}{l}\text { Besser } \\
\text { et al., } \\
2012[46]\end{array}$ & Medicine & $\begin{array}{l}\text { This study conducted interviews with patients } \\
\text { with osteoporosis and collected their drawings } \\
\text { to assess their views on the illness and } \\
\text { treatment, as well as their conditions. }\end{array}$ & $\begin{array}{l}\text { Doctor-patient relationship was reported as } \\
\text { one motivation to adhere to medication } \\
\text { regimen. }\end{array}$ \\
\hline & $\begin{array}{l}\text { Cronin } \\
\text { et al., } \\
2014[47]\end{array}$ & $\begin{array}{l}\text { Other } \\
\text { (genetic } \\
\text { engineering) }\end{array}$ & $\begin{array}{l}\text { This study introduced "Issues Mapping" to } \\
\text { facilitate dialogues between different } \\
\text { stakeholders, clarify different perspectives, and } \\
\text { promote mutual understanding. It applied the } \\
\text { techniques to social conflicts relating to genetic } \\
\text { engineering issues. }\end{array}$ & $\begin{array}{l}\text { Perceptions of genetic engineering including } \\
\text { participants' trust in other stakeholders and } \\
\text { their views on current debate in society. }\end{array}$ \\
\hline \multirow{2}{*}{$\begin{array}{l}\text { Decision } \\
\text { making and } \\
\text { behavior } \\
\text { change }\end{array}$} & $\begin{array}{l}\text { Lopez- } \\
\text { Gonzalez } \\
\text { et al., } \\
2015[9]\end{array}$ & Medicine & $\begin{array}{l}\text { This was an intervention study to see if } \\
\text { communicating to people about cardiovascular } \\
\text { diseases (CVDs) by using risk assessment tools } \\
\text { (Framingham REGICOR and Heart Age) } \\
\text { would lead to improvement in their CVD risk } \\
\text { factors. }\end{array}$ & $\begin{array}{l}\text { Changes in physical activity (number of } \\
\text { sessions of physical activity per week), } \\
\text { smoking behavior, and other modifiable risk } \\
\text { factors, involving anthropometrical and } \\
\text { blood pressure data. }\end{array}$ \\
\hline & $\begin{array}{l}\text { Rabinovich } \\
\text { et al., } \\
2012[48]\end{array}$ & $\begin{array}{l}\text { Climate } \\
\text { change }\end{array}$ & $\begin{array}{l}\text { This study assessed the effect of people's } \\
\text { beliefs about nature and science on their } \\
\text { perspective about uncertainty in relation to } \\
\text { climate change. }\end{array}$ & $\begin{array}{l}\text { Participants' willingness to carry out positive } \\
\text { environmental behaviors (e.g., reducing } \\
\text { water use) and agree on a household carbon } \\
\text { budget. }\end{array}$ \\
\hline
\end{tabular}




\begin{tabular}{|c|c|c|c|c|}
\hline \multirow[t]{2}{*}{$\begin{array}{l}\text { Self-efficacy } \\
\text { improvement }\end{array}$} & $\begin{array}{l}\text { Harris } \\
\text { et al., } \\
2013[49]\end{array}$ & Medicine & $\begin{array}{l}\text { This study analyzed the influence of parents' } \\
\text { marital status, and parent-child sexual } \\
\text { communication and relationship on male } \\
\text { adolescents' knowledge regarding HIV and } \\
\text { STDs, and their intentions and their } \\
\text { implementation of preventive behaviors. }\end{array}$ & $\begin{array}{l}\text { Six-item Condom Use Self-Efficacy scale } \\
\text { (e.g., "I am confident that I know how to use } \\
\text { a condom.") }\end{array}$ \\
\hline & $\begin{array}{l}\text { Feenstra } \\
\text { et al., } \\
2014[36]\end{array}$ & $\begin{array}{l}\text { Other } \\
\text { (traffic } \\
\text { safety) }\end{array}$ & $\begin{array}{l}\text { This study assessed the impacts of a school- } \\
\text { based road safety program on risk perception, } \\
\text { attitude, intention, and behaviors in relation to } \\
\text { risky cycling among } 9 \text { th- } 11 \text { th-grade students. }\end{array}$ & $\begin{array}{l}\text { Perceived self-efficacy for safe cycling (e.g., } \\
\text { controlling the bicycle and applying traffic } \\
\text { rules) in comparison with peers. }\end{array}$ \\
\hline
\end{tabular}




\section{Table 3(on next page)}

Intervention timing, target audience, and communication type by study field $(\mathrm{N}=292)$. 
Table 3. Intervention timing, target audience, and communication type by study field $(N=292)$.

\begin{tabular}{|c|c|c|c|c|c|c|c|c|}
\hline & \multicolumn{7}{|c|}{ Study field } \\
\hline & & $\begin{array}{l}\text { Medicine } \\
(n=184)\end{array}$ & $\begin{array}{c}\text { Food } \\
\text { safety } \\
(n=18)\end{array}$ & $\begin{array}{c}\text { Chemical } \\
\text { substances } \\
(n=17)\end{array}$ & $\begin{array}{c}\text { Nuclear } \\
\text { and } \\
\text { radiologica } \\
\text { 1 disasters/ } \\
\text { emergenci } \\
\text { es } \\
(n=6)\end{array}$ & $\begin{array}{c}\text { Other } \\
\text { disasters/ } \\
\text { emergenci } \\
\text { es } \\
(n=27)\end{array}$ & $\begin{array}{l}\text { Climate } \\
\text { change } \\
(n=5)\end{array}$ & $\begin{array}{c}\text { Other } \\
(n=40)\end{array}$ \\
\hline & & $n(\%)$ & $n(\%)$ & $n(\%)$ & $n(\%)$ & $n(\%)$ & $n(\%)$ & $n(\%)$ \\
\hline \multirow{3}{*}{$\begin{array}{l}\text { Intervention } \\
\text { timing }\end{array}$} & Non-/pre-crisis & $174(95)$ & $16(89)$ & $16(94)$ & $3(50)$ & $22(81)$ & $5(100)$ & $40(100)$ \\
\hline & Crisis & $9(5)$ & $1(6)$ & $1(6)$ & $0(0)$ & $4(15)$ & $0(0)$ & $0(0)$ \\
\hline & Post-crisis & $1(1)$ & $2(11)$ & $0(0)$ & $3(50)$ & $1(4)$ & $0(0)$ & $0(0)$ \\
\hline \multirow{2}{*}{$\begin{array}{l}\text { Target } \\
\text { audience }\end{array}$} & Citizens/NPOs & $164(89)$ & $18(100)$ & $14(82)$ & $5(83)$ & $27(100)$ & $5(100)$ & $39(98)$ \\
\hline & Other & $31(17)$ & $0(0)$ & $5(29)$ & $1(17)$ & $0(0)$ & $0(0)$ & $3(8)$ \\
\hline \multirow[t]{2}{*}{$\begin{array}{l}\text { Communicatio } \\
\text { n type }\end{array}$} & $\begin{array}{l}\text { Individual/small group } \\
\text { communication }\end{array}$ & $91(49)$ & $0(0)$ & $4(24)$ & $1(17)$ & $6(22)$ & $0(0)$ & $2(5)$ \\
\hline & $\begin{array}{l}\text { Large group } / \text { mass } \\
\text { communication }\end{array}$ & $96(52)$ & $18(100)$ & $15(88)$ & $5(83)$ & $23(85)$ & $5(100)$ & $38(95)$ \\
\hline
\end{tabular}

Although the total number of studies included in the analysis was 292, the total number of each variable varies owing to the allowance of multiple responses. The percentages were based on the total number of each study field. 


\section{Table 4 (on next page)}

Study field, intervention timing, target audience, and communication type by objective/evaluation indicator $(\mathrm{N}=292)$. 
Table 4. Study field, intervention timing, target audience, and communication type by objective/evaluation indicator $(N=292)$.

\begin{tabular}{|c|c|c|c|c|c|c|c|c|c|}
\hline & & \multicolumn{8}{|c|}{ Objective/evaluation indicator } \\
\hline & & $\begin{array}{c}\text { Knowledg } \\
\text { e } \\
\text { increase }\end{array}$ & $\begin{array}{l}\text { Communicatio } \\
\text { n satisfaction }\end{array}$ & $\begin{array}{l}\text { Change in } \\
\text { risk } \\
\text { perception } \\
\text { and concern } \\
\text { alleviation }\end{array}$ & $\begin{array}{l}\text { Reduction in } \\
\text { psychologic } \\
\text { al distress }\end{array}$ & $\begin{array}{l}\text { Trust } \\
\text { buildin } \\
\mathrm{g}\end{array}$ & $\begin{array}{l}\text { Decision } \\
\text { making } \\
\text { and } \\
\text { behavior } \\
\text { change } \\
\end{array}$ & $\begin{array}{c}\text { Self- } \\
\text { efficacy } \\
\text { improveme } \\
\text { nt }\end{array}$ & Other \\
\hline & & $n(\%)$ & $n(\%)$ & $n(\%)$ & $n(\%)$ & $n(\%)$ & $n(\%)$ & $n(\%)$ & $n(\%)$ \\
\hline \multirow[t]{7}{*}{ Study field } & Medicine $(n=184)$ & $78(42)$ & $37(20)$ & $67(36)$ & $6(3)$ & $10(5)$ & $115(63)$ & $10(5)$ & $8(4)$ \\
\hline & Food safety $(n=18)$ & $7(39)$ & $5(28)$ & $10(56)$ & $0(0)$ & $4(22)$ & $8(44)$ & $0(0)$ & $1(6)$ \\
\hline & $\begin{array}{l}\text { Chemical substances } \\
(n=17)\end{array}$ & $9(53)$ & $1(6)$ & $7(41)$ & $1(6)$ & $0(0)$ & $13(76)$ & $0(0)$ & $0(0)$ \\
\hline & $\begin{array}{l}\text { Nuclear and } \\
\text { radiological } \\
\text { disasters/emergencies } \\
(n=6)\end{array}$ & $3(50)$ & $1(17)$ & $3(50)$ & $0(0)$ & $1(17)$ & $2(33)$ & $0(0)$ & $0(0)$ \\
\hline & $\begin{array}{l}\text { Other } \\
\text { disasters/emergencies } \\
(n=27)\end{array}$ & $7(26)$ & $1(4)$ & $16(59)$ & $0(0)$ & $5(19)$ & $16(59)$ & $1(4)$ & $2(7)$ \\
\hline & Climate change $(n=5)$ & $1(20)$ & $0(0)$ & $3(60)$ & $0(0)$ & $0(0)$ & $2(40)$ & $0(0)$ & $0(0)$ \\
\hline & Other $(n=40)$ & $13(33)$ & $2(5)$ & $25(63)$ & $0(0)$ & $3(8)$ & $22(55)$ & $2(5)$ & $2(5)$ \\
\hline \multirow[t]{3}{*}{$\begin{array}{l}\text { Intervention } \\
\text { timing }\end{array}$} & $\begin{array}{l}\text { Non-/pre-crisis } \\
(n=273)\end{array}$ & $107(39)$ & $44(16)$ & $124(45)$ & $7(3)$ & $19(7)$ & $168(62)$ & $13(5)$ & $12(4)$ \\
\hline & Crisis $(n=14)$ & $3(21)$ & $1(7)$ & $2(14)$ & $0(0)$ & $3(21)$ & $8(57)$ & $0(0)$ & $1(7)$ \\
\hline & Post-crisis $(n=6)$ & $5(83)$ & $2(33)$ & $3(50)$ & $0(0)$ & $1(17)$ & $2(33)$ & $0(0)$ & $0(0)$ \\
\hline \multirow[t]{2}{*}{$\begin{array}{l}\text { Target } \\
\text { audience }\end{array}$} & $\begin{array}{l}\text { Citizens/NPOs } \\
(n=267)\end{array}$ & $106(40)$ & $46(17)$ & $119(45)$ & $6(2)$ & $20(7)$ & $163(61)$ & $13(5)$ & $12(4)$ \\
\hline & Other $(n=40)$ & $15(38)$ & $5(13)$ & $10(25)$ & $2(5)$ & $3(8)$ & $24(60)$ & $1(3)$ & $2(5)$ \\
\hline \multirow[t]{2}{*}{$\begin{array}{l}\text { Communicatio } \\
\text { n type }\end{array}$} & $\begin{array}{l}\text { Individual/small group } \\
\text { communication } \\
(n=104)\end{array}$ & $42(40)$ & $19(18)$ & $33(32)$ & $5(5)$ & $5(5)$ & $74(71)$ & $5(5)$ & $6(6)$ \\
\hline & $\begin{array}{l}\text { Large group/mass } \\
\text { communication } \\
(n=195)\end{array}$ & $75(38)$ & $28(14)$ & $96(49)$ & $2(1)$ & $17(9)$ & $110(56)$ & $9(5)$ & $7(4)$ \\
\hline OVERALL & $(N=292)$ & $115(39)$ & $47(16)$ & $128(44)$ & $7(2)$ & $22(8)$ & $177(61)$ & $13(4)$ & $13(4)$ \\
\hline
\end{tabular}

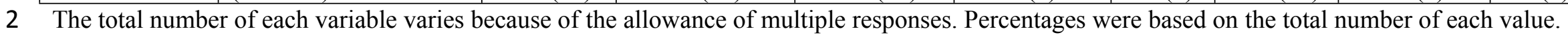

